Krzysztof Rzepa

(Uniwersytet im. Adama Mickiewicza w Poznaniu, Wydział Historyczny) prof. UAM dr hab., rzepa@amu.edu.pl

\title{
Nostalgia i rewolucyjny zapał - na obrzeżach PZPR: Poznańskie Forum Komunistyczne i Komunistyczny Związek Młodzieży Polskiej w Wielkopolsce w 1981 r.
}

Sierpień 1980 r. był dla PZPR wstrząsem. Zachwiał jej ideologicznymi fundamentami oraz podstawami organizacyjnymi. Wkrótce po podpisaniu porozumień z załogami strajkujących zakładów powstawać zaczęły struktury nowych związków zawodowych, które bardzo szybko zrzeszyły zdecydowaną większość pracowników największych zakładów przemysłowych, wśród których było także wielu członków partii. To w oczywisty sposób podważyło jedną z pryncypialnych przesłanek służących uzasadnieniu jej przewodniej roli w państwie jako reprezentacji wiodącej w niej klasy robotniczej. Nie sposób było więc uciec od pytania o przyczyny exodusu członków partii do co bardzo szybko stało się oczywiste - ideowego i organizacyjnego rywala, a tym samym zaczęto $w$ jej niektórych środowiskach podejmować inicjatywy zmierzające do wyjścia z głębokiego kryzysu, w jakim znalazła się PZPR. Najbardziej widocznym przejawem zapaści była erozja partyjnych szeregów. Do końca 1980 r. opuściło je w województwie poznańskim wprawdzie stosunkowo niewielu członków, ale przeważali wśród nich robotnicy ${ }^{1}$. Początkowo na krok taki zdecydowało się tu stosunkowo niewielu, gdyż z chwilą rejestracji Solidarności (10 listopada 1980 r.) spośród członków związku zawodowego (ok. trzysta tys. osób) do PZPR należało zaledwie pięć proc. - a więc ok. piętnaście tys. ${ }^{2}$ Później jednak początkowa ostrożność ustąpiła, na co pe-

\footnotetext{
${ }^{1}$ A. Choniawko, PZPR w Wielkopolsce 1948-1984, Poznań 1987, s. 253.

${ }^{2}$ Był to ewenement, gdyż średnia krajowa partycypacja członków partii w związku wyniosła wówczas 15,8 proc. Wśród pozostałych wielkopolskich województw przodowało w tym względzie konińskie - 28,1 proc., ale i ono znacznie ustępowało krajowemu "prymusowi” województwu słupskiemu, gdzie wśród członków związku do partii należało ich aż 37 proc.; patrz: .W. Jankowski, Członkowie Polskiej Zjednoczonej Partii Robotniczej wobec wprowadzenia stanu
} 
wien wpływ miała najpewniej sugestia władz partii zachęcająca do wstępowania w szeregi Solidarności, aby ją opanować. Kierownictwo PZPR, również w Poznaniu, zmierzało do nadania nowemu związkowi „,zdrowego, robotniczego charakteru" i wręcz zachęcało, aby zgłaszać do niego akces ${ }^{3}$. Nie to jednak było źródłem sukcesu Solidarności. Przeważyło masowe poparcie dla nowego związku, będące wyrazem protestu wobec ówczesnej rzeczywistości, a więc kryzysu ekonomicznego, obarczenia odpowiedzialnością za doprowadzenie do niego i bezradnością w jego zaradzeniu ze strony władz. Już niebawem w szeregach wielkopolskiej Solidarności znaleźć się miała zdecydowana większość zatrudnionych w uchodzących za twierdze socjalizmu największych zakładach przemysłowych w regionie. Nadzieja aparatu partyjnego, że wystarczą zmiany personalne i niewielkie kosmetyczne zmiany, okazała się nie tylko złudna, ale również nie do zaakceptowania przez to skrzydło w PZPR, które chciało ją zliberalizować. W tym też gronie zaczęto oddolnie działać na rzecz odrodzenia partii, która - według jej reformatorów - aby przetrwać, nie mogła trwać w dotychczasowym kształcie.

Zaczęto od krytycznej diagnozy kryzysów, jakimi targana była Polska ludowa. Analiza taka miała pomóc znaleźć wyjście z najnowszego załamania, którego źródeł dopatrywano się właśnie w partii i polityce jej kierownictwa. Toteż już w tydzień po podpisaniu porozumień na Wybrzeżu w uchwale przyjętej na przez organizację PZPR w Polskiej Akademii Nauk stwierdzano, że „najbardziej niebezpiecznym dla losów socjalizmu w Polsce elementem kryzysu jest kryzys w partii, czemu towarzyszy nieufność społeczeństwa i członków partii wobec [jej] kierownictwa”. I konstatowano: „Partia straciła tak wiele, że więcej tracić nie może. Przekonani o tym wnosimy o zwołanie nadzwyczajnego zjazdu partii" ${ }^{4}$. Deklarację tę można było potraktować jako sygnał do odnowy partii, który został podjęty przez wiele jej organizacji na różnych szczeblach w całym kraju. Najdalej i najpełniej szli działacze grupy, która zawiązała się w Toruniu, gdzie pod koniec października przedstawiciele kilku organizacji partyjnych z miejscowych zakładów pracy utworzyli Komisję Konsultacyjno-Porozumiewawczą. Komisja ta, której przewodził Zbigniew Iwanów, stała się symbolem i wzorem dla podobnych struktur poziomych wewnątrz PZPR ${ }^{5}$. Z entuzjazmem o tych inicjatywach pisał w Poznaniu socjolog UAM Michał Chmara, który podkreślał, iż w nich

wojennego, [w:] Kościót i społeczeństwo wobec stanu wojennego, red. W.J. Wysocki, Warszawa 2004, s. $451-453$.

${ }^{3}$ J. Kusiak mówił 15 listopada 1980 r.: „ „[...] poszliśmy na kształtowanie tej »Solidarności« w zakładach pracy", patrz: Narady i telekonferencje kierownictwa PZPR w latach 1980-1981, red. M. Jabłonowski, W. Janowski, W. Władyka, Warszawa 2004, s. 389.

${ }^{4}$ E. Duraczyński, PZPR w kryzysie - kryzys w PZPR (lato 1980-lato1981), „Dzieje Najnowsze” 1997, nr 4, s. 79.

${ }^{5}$ Szerzej R Bäcker, Struktury poziome w Toruniu: (1980-1981), Warszawa 1990, s. 11 i n. 
właśnie „skrystalizował się w chwili obecnej napór członków partii niezadowolonych z kunktatorstwa i niezdolności do wielu instancji partyjnych do zrozumienia momentu historycznego. Niezadowolenie to dotyczy także niewywiązywania się przez instancje $\mathrm{z}$ elementarnego zadania statutowego tworzenia i realizowania programu politycznego reprezentującego rzeczywiste interesy klasy pracującej (na poziomie myśli strategicznej), a nie tylko taktycznej i to w wersji najsłabszej - doraźnego manewru i obronnego fortelu"6.

To właśnie przyświecało kolegom Chmary w Poznaniu, gdzie po uchwałach podjętych przez działaczy uczelnianej organizacji partyjnej UAM, w których już na przełomie września i października 1980 r. przedstawiano „propozycje działań odbudowujących jej przewodnictwo w budowie socjalizmu prawdziwie demokratycznego sensu", w listopadzie zwrócono się z propozycją współpracy na tym polu do czołowego poznańskiego zakładu pracy HCP. I takie porozumienie zostało 20 listopada $1980 \mathrm{r}$. zawarte ${ }^{7}$. To ono otwierało możliwość przezwyciężenia oporu dogmatycznej części członków partii, a zwłaszcza jej aparatu, przed zmianami, które $\mathrm{w}$ ich oczach były niezbędne, aby PZPR mogła przetrwać. Porozumienie stało się podstawą do wyłonienia dwóch ściśle ze sobą zespolonych gremiów, koncepcyjnego i organizacyjnego, które miały przygotować partię do nadzwyczajnego zjazdu. Zostały one utworzone oddolnie, wbrew intencjom Komitetu Wojewódzkiego PZPR w Poznaniu, które zamierzało kontrolować przygotowania do zjazdu partii.

W połowie stycznia 1981 r. powstało Poznańskie Forum Myśli Politycznej "Dialog”, które zostało utworzone przez partyjne organizacje poznańskich zakładów przemysłowych i tamtejszych uczelni wyższych ${ }^{8}$. Za sprawą pełnomocnictwa otrzymanego od ponad 120 organizacji partyjnych z największych zakładów w województwie poznańskim uzyskało wielki wpływ na kształt dyskusji o przyszłości partii nie tylko w Poznańskiem, ale także w Wielkopolsce, gdyż inspirowało prących do zmian działaczy PZPR, co dało się dostrzec $\mathrm{w}$ drugim po Poznaniu wielkim skupisku wielkoprzemysłowej klasy robotniczej, a więc w Koninie9.

To właśnie ono nadało ton ukonstytuowanemu już pod koniec grudnia 1980 r. Wojewódzkiemu Zespołowi Zjazdowemu, do którego jak najwcześniejszego powołania parły organizacje partyjne UAM i HCP. Jedną z pierw-

\footnotetext{
${ }^{6}$ „Lewą! Biuletyn Dyskusyjny Uniwersyteckiej Organizacji Partyjnej” 1980, nr 1 [grudzień], s. 4.

${ }^{7}$ Tamże, s. 3, 5 .

8 „Biuletyn Komitetu Wojewódzkiego PZPR w Poznaniu” nr 2 z 12 lutego 1981 r.; później z nazwy zniknęło słowo „Dialog”.

9 Patrz: „Gazeta Poznańska”, nr 204 z 16 października 1981 r.; Z. Bosacki, Jeśli dziś nie wolno, to nie wolno się bać - tekst przygotowany do druku w poznańskim „Tygodniu”, który się nie ukazał po wprowadzeniu stanu wojennego (tekst udostępniony przez autora).
} 
szych uchwał, jakie zostały podjęte przez to gremium, było wystąpienie do Komitetu Wojewódzkiego PZPR z wnioskiem, aby ten na najbliższym swym posiedzeniu podjął decyzję o przeprowadzeniu wyborów na wszystkich szczeblach $w$ okresie przygotowań do nadzwyczajnego zjazdu ${ }^{10}$. Najwięcej emocji budziła jednak śledcza aktywność powstałego w ramach WZZ IX zespołu, który zajął się nadużyciami popełnionymi przez przedstawicieli lokalnych władz ${ }^{11}$.

Tym samym to w kręgu WZZ oraz PFMP ulokował się ośrodek, który miał przygotować partię do zmian. W cień zepchnięty został dotychczas decydujący o tym aparat partyjny, czemu dano symbolicznie wyraz, zbierając się poza siedzibą KW. Rzecz jasna, spotkało się to z niezadowoleniem dotychczasowych działaczy, czemu jednoznacznie dał wyraz jeden z ich przedstawicieli. Pod koniec stycznia 1981 r. ówczesny zastępca kierownika Wydziału Administracyjnego KW PZPR w Poznaniu Michał Kolasiński pisał: „, [...] radykalnie zmieniła się sytuacja w partii. Dawniej partia to było mądre kierownictwo, zapatrzone $w$ tę mądrość podległe instancje wraz z tak zwanymi masami partyjnymi. Teraz to jest szczyt galimatiasu. Za wszystko, co się w Polsce wydarzyło, obwiniono partię przeciwstawiając ją społeczeństwu. Z kolei wszystko, co złe w partii, przypisano aparatowi przeciwstawiając go partii. Pracowników aparatu podzielono na tych, którzy dawno już powinni być oddani pod sąd za korupcję i złodziejstwo, oraz na tych, którzy może mają czyste ręce i sumienie, ale tolerowali wszelkie draństwo, powinni więc szybko podać sie do dymisji, ponieważ są niewiarygodni. IX Zjazd przygotowuje u nas ukonstytuowany poza KW Wojewódzki Zespół Zjazdowy, eliminujący właściwie instancję i jej aparat z prac koncepcyjnych"12.

Oponenci skrzydła reformatorskiego w poznańskiej organizacji PZPR zostali wprawdzie zmarginalizowani, ale się nie poddawali. Partyjny "beton” miał prawo sądzić, iż nie wszystko stracone. W największych organizacjach to właśnie jego przedstawiciele stanęli na ich czele, w Katowicach Andrzej Żabiński (wrzesień 1980 r.), a w Warszawie Stanisław Kociołek (listopad

10 „Lewą" 1981, nr 2 [styczeń], s. 3; nr 3 [luty], s. 1.

${ }^{11}$ Inicjatorem powołania tego zespołu był przedwojenny działacz komunistyczny Jan Brygier, patrz: tegoż, Trudne lata 1980-1984, s. 6 (maszynopis nieopublikowanych wspomnień Brygiera, udostępniony autorowi przez Edwarda Skrzypczaka).

${ }^{12}$ M. Kolasiński, Zapiski nie tylko autobiograficzne, cz. III, Poznań 2008, s. 29 (maszynopis udostępniony przez autora); Kolasiński stanął w obronie "aparatu” w odpowiedzi na zamieszczony w "Gazecie Zachodniej” nr 71 z 10 kwietnia 1981 r. - jak pisał - „zainspirowany owymi tezami paszkwil na pracowników KW pod tytułem Przyczynek do teorii bunkra. Nikt z pracowników partyjnych ani z grona aktywu nie podjął dyskusji, nie stanął $\mathrm{w}$ obronie oblewanych pomyjami »partyjnych wyrobników«. Jako jedyny zabrałem głos, co »Gazeta« wydrukowała dopiero 11 maja”. Tytuł publikacji polemizującej z autorami „teorii bunkra”: patrz: „Gazeta Zachodnia" nr 91 z 11 maja 1981 r. 
1980 r. $)^{13}$. Początkowo nie podejmował bardziej zdecydowanych działań, wierząc, iż jego siłą jest partyjny aparat, ale wielkie sukcesy Solidarności oraz dynamicznie rozwijający się ruch wewnątrz partii na rzecz jej liberalizacji sprawiły, że przystąpił do ataku. Już wczesną wiosną pojawiła się w Poznaniu odezwa, która wzywała do obrony "partii i socjalizmu”, a jej autorzy wyraźnie dawali do zrozumienia, że gotowi są do tego "na śmierć i życie”. Dokument był sygnowany przez tzw. Komitet Obrony Partii i Socjalizmu, który - jak napisano - działa w największych poznańskich zakładach pracy. Komitet ten miał się zawiązać $\mathrm{w}$ proteście przeciw oddolnym inicjatywom organizacji partyjnych szkół wyższych, które zainicjował KU Politechniki Poznańskiej, a usiłujących uruchomić procedury zmierzające do dokonania zmian $\mathrm{w}$ regionalnych władzach partii. Ten anonimowy apel, adresowany także do Konsulatu ZSRR w Poznaniu, dość jednoznacznie wskazywał na autorów inicjatywy, którzy jednak woleli pozostać anonimowi. Dla PZPR „odnowa" stała się niezbędną, aby przetrwać, czego świadomi byli reformatorzy, ale to spędzało sen z oczu ortodoksom i partyjnemu aparatowi, dążącemu do zachowania status quo. Świadomość, iż reformy w partii są nieodzowne, stawała się wśród znacznej części działaczy tak silna, iż ich przeciwnicy jeszcze woleli pozostawać anonimowi. To właśnie wytykał im stojący wówczas na czele uniwersyteckiej organizacji partyjnej Jacek Trojanek, który mówił o inicjatywie "ludzi bez twarzy"14.

Pod koniec kwietnia na łamach poznańskiego organu PZPR ukazał się tekst, w którym krytyce poddano pasywną postawę tamtejszego kierownictwa partii. Jej autor Wojciech Kornowski był zaledwie kierownikiem zaopatrzenia w spółdzielni Plastgum produkującej zabawki z tworzyw sztucznych, ale jego ówczesnym teściem był sekretarz organizacyjny KW PZPR Feliks Siemiankowski. Kornowski pisał: „[...] dziś, gdy toczy się walka polityczna -

${ }^{13}$ E. Duraczyński, dz. cyt., s. 81.

14 „Lewą!" 1981, nr 5, s. 2. Występując 18 marca 1981 r. na II Plenum Wojewódzkiego Zespołu Zjazdowego PZPR, Trojanek mówił o ludziach w partii, którzy „do dzisiaj nie zrozumieli - lub nie chcą zrozumieć - tego co się stało w tym kraju w 1980 roku, którzy nie rozumieją od czego zależy los partii”. W odezwie Komitetu Obrony Partii i Socjalizmu pisano: „[...] My, wierni partii i socjalizmowi robotnicy pracownicy umysłowi, musimy schodzić do podziemia, ale jesteśmy zdecydowani bronić socjalizmu w Polsce na śmierć i życie". Pojawiły się w niej wręcz kuriozalne sformułowania: „nasze dzieci przychodzą do domu z płaczem, bo nie są przygotowane do odpierania ataków świętej inkwizycji, głębokiego średniowiecza z nowoczesnymi metodami łamania ludzkich charakterów, w imię wątpliwej jakości ideałów. Czyż arogancja, terror pod różnymi postaciami, nietolerancja religijna, szykany, prześladowania ludzi broniących socjalizmu, ma być cechą »nowej demokracji«? Czy uczelnie mają wychowywać terrorystów, teokratów i bojówkarzy h[i]tlerowskich SA, SS i HJ? My wierni partii i socjalizmowi robotnicy i pracownicy umysłowi musimy schodzić do podziemia, ale jesteśmy zdecydowani bronić socjalizmu na śmierć i życie". Nie sposób wykluczyć, że rzeczywiste autorstwo tej „odezwy” przypisać można SB. 
milczenie, bierne kibicowanie to zdrada ideałów partii"15. A więc w PZPR nie brakowało ludzi, którzy nie zamierzali ugiąć przed presją dokonywania zasadniczych zmian $w$ szeregach organizacji. Już wkrótce skupione w tym kręgu grono postanowiło przejść od słów do czynu. Aktywność środowisk zmierzających do zmian, które zyskiwały wyraźne poparcie $\mathrm{w}$ trakcie wyborów delegatów na nadzwyczajny zjazd partii, spychała ich do defensywy. Grupa ta nie zamierzała jednak ustępować.

Jak pisze Eugeniusz Duraczyński, to zachowawcze skrzydło w PZPR składało się z „nielicznej grupy ortodoksyjnych ideologów, których abstrakcyjne schematy myślowe nie trafiały już praktycznie do nikogo oraz z doświadczonych w sprawowaniu władzy, różnego szczebla funkcjonariuszy aparatu państwowego i partyjnego. Ci, wraz ze swoimi ideologami, nawoływali do oczyszczenia socjalizmu z wypaczeń epoki gierkowskiej, przekonywali do tego systemu wartości, jakie - ich zdaniem - wniósł do ruchu robotniczego leninizm, optowali za istotnymi korektami w polityce gospodarczej, niechętnie odnosili do jakiejś szerszej i głębszej liberalizacji systemu politycznego, podejrzliwie odnosili się do realistów i pragmatyków, dążyli do radykalnej pacyfikacji »Solidarności«, a najlepiej jej likwidacji"16. Wobec wzmożonej aktywności środowisk prących do liberalizacji PZPR, grupy zachowawcze, skupione wokół kierujących warszawską (Kociołek) i górnośląską organizacją partyjną (Żabiński), uzyskały ich wsparcie i już wkrótce mogły rozwinąć swoją organizacyjną działalność ${ }^{17}$.

Krytyczne poglądy odrzucające liberalizację PZPR wyrażać mogli na łamach wydawanego od końca maja 1981 r. tygodnika. „Rzeczywistość”, który powstał z inicjatywy ortodoksyjnego kręgu działaczy PZPR i rozpowszechniany w dużym nakładzie (150 tys.) hołdował poglądom określanym niekiedy jako narodowo-bolszewickie, ale otwarty był również dla opinii formuło-

15 „Gazeta Zachodnia” nr 83 z 29 kwietnia 1981 r.; o Kornowskim patrz: M. Kolasiński, dz. cyt., s. 74-76.

${ }^{16}$ E. Duraczyński, dz. cyt., s. 85-86; podobnie cele tej grupy przedstawia P. Gasztold-Seń: „Skrzydło »twardogłowych« postulowało siłowe i bezpardonowe rozwiązanie konfliktu z niezależnym związkiem zawodowym. Domagało się ofensywy ideologicznej partii, sprzeciwiając się próbom jej wewnętrznej reformy w postaci struktur poziomych", tegoż, „Lewica" PZPR. Działalność Stowarzyszenia Klubów Wiedzy Społeczno-Politycznej „Rzeczywistość" w latach 1981-1983, [w:] Letnia Szkoła Historii Najnowszej, red. Ł. Kamiński i T. Kozłowski, Warszawa 2010, s. 77.

${ }^{17}$ W Warszawie od lutego 1981 r. działał noszący nazwę Klub Warszawa 1980, a w Katowicach w maju tego roku rozpoczęło działalność Forum Partyjne, patrz: P. Gasztold-Seń, Koncesjonowany nacjonalizm. Zjednoczenie Patriotyczne Grunwald 1980-1990, Warszawa 2012, s. 49 i n.; J. Kazimierski, Katowickie Forum Partyjne, „Pamięć i Sprawiedliwość” 2013, t. 22, nr 2, s. 212. 
wanych przez grupy odwołujące się werbalnie do dogmatycznego komuni$\mathrm{zmu}^{18}$.

W czerwcu 1981 r. grupa "twarogowych" działaczy partyjnych, idąc w ślady górnośląskich przeciwników zmian w PZPR, zebrała się w siedzibie KW PZPR i powołała do życia Poznańskie Forum Komunistów, na którego czele stanął Jan Majerczak. Niestety, z powodu braku zachowanych materiałów źródłowych nie sposób odtworzyć kulis tej decyzji ani nazwisk osób, które za tą inicjatywą się kryły. Jej twarzą stał się Majerczak, działacz partyjny średniego szczebla, który swój społeczny awans w decydującej mierze zawdzięczał PZPR, przebywając kilka lat poza krajem - nie tylko nie rozumiał, ale i nie potrafił się odnaleźć w nowej, złożonej polskiej rzeczywistości ${ }^{19}$. Po powrocie do kraju w 1980 r. z Czechosłowacji, gdzie przez kilka lat był konsulem, został dyrektorem Zakładów Systemów Automatyki MERA w Poznaniu. Skonfrontował się wówczas z wydarzeniami, które nie tylko kłóciły się z jego zasadami, ale wręcz burzyły jego świat. Postanowił więc działać, aby ten znów przystawał do jego ideowych przekonań. Pełniąc stanowisko dyrektorskie, wykorzystał je do działalności politycznej i polecał swoim pracownikom powielanie materiałów, w których nawoływał władze partyjne do zawrócenia organizacji z błędnej drogi, wiodącej ją - jego zdaniem - na ideowe manowce ${ }^{20}$.

PFK nie przypadkiem zdecydowało się zawiązać i wystąpić publicznie z rezolucją 16 czerwca 1981 r. Inspiracji dostarczyła krytyczna ocena przemian zachodzących w Polsce, która znalazła się w liście KC KPZR skierowanym 5 czerwca do kierownictwa PZPR. Nadto wybory delegatów na partyjną wojewódzką konferencję sprawozdawczo-wyborczą nie pozastawiały złudzeń - przeciwnicy zmian w partii zostaną zmajoryzowani. Tworząc więc swoje wewnątrzpartyjne forum, odwołano się do inspiracji zewnętrznej (list kierownictwa partii radzieckiej), wsparto się nadto argumentem o solidarno-

${ }^{18}$ P. Gasztold-Seń, Koncesjonowany, s. 232 i n.

${ }^{19}$ Jan Majerczak (ur. 1926 r. w Piaskowie, pow. szamotulski), działalność w ruchu komunistycznym rozpoczął od niższych szczebli w organizacjach młodzieżowych (ZWM, ZMP), od 1951 r. w PZPR, gdzie był: członkiem egzekutywy KP we Wrześni (1952-1954), sekretarzem organizacyjnym KP w Kępnie (1954-1955), od 1955 r. do 1958 r. I sekretarzem tamtejszej organizacji powiatowej PZPR. Po ukończeniu w $1961 \mathrm{r}$. WSNS przy KC PZPR został instruktorem KW w Poznaniu. W 1963 r. został I sekretarzem KP w Ostrowie Wlkp., w 1966 r. wybrany członkiem KW PZPR w Poznaniu. Organizacją partyjną w Ostrowie kierował do 1973 r., wtedy został delegowany na jednoroczne Podyplomowe Studium Służby Dyplomatycznej WSNS przy KC PZPR. Po jego ukończeniu w 1974 r. został wysłany na placówkę konsularną w Czechosłowacji, gdzie pełnił funkcję Generalnego Konsula. APP, KW PZPR, sygn. 12283. Zmarł w 2016 r. w Poznaniu.

${ }^{20}$ Zarzut ten stał się na początku 1982 r. podstawą do wykluczenia Majerczaka z szeregów PZPR, co było dość wygodnym, ale też wątpliwym statutowo pretekstem do pozbycia się tego ortodoksyjnego działacza, patrz: APP, KW PZPR, sygn. 3579, k. 32. 
ści z towarzyszami z forum katowickiego, którzy odważnie wystąpili przeciwko zmianom w PZPR ${ }^{21}$. Forum katowickie, które powstało w połowie maja 1981 r. z inspiracji tamtejszego I sekretarza KW Żabińskiego, jednego z czołowych reprezentantów nurtu konserwatywnego w partii, stało się emanacją ruchu sprzeciwu wobec wymuszonych robotniczym buntem zmian w PZPR ${ }^{22}$. W swojej pierwszej rezolucji z czerwca PFK podkreślało więc, że w pełni podziela krytyczną ocenę sytuacji w Polsce i w PZPR, która została sformułowana w Moskwie. A zatem nie omieszkano podkreślić, że "trzeba aktywnie przeciwstawić się [...] totalnemu negowaniu dorobku Polski Ludowej". Za krzywdzące uznano opinie, w których się "wyolbrzymia błędy gospodarcze", ale powątpiewano, czy rzeczywiście one są źródłem problemów. Przecież jak podkreślano, „marginesowo, lub wcale nie ocenia się skutków oraz odpowiedzialności za rozbijanie ideologiczne partii, za pozostawienie dużej swobody dla działalności sił opozycyjnych w latach 70 -tych" ${ }^{23}$. A więc mniej istotny był głęboki kryzys, gospodarcze załamanie, za które odpowiedzialność ponosiła rządząca PZPR, niźli ideologiczna homogeniczność i godzenie w jej zasady ze strony krytyków! W pierwszej rezolucji PFK niezwykle pozytywnie oceniono działalność forum katowickiego, które zapoczątkowało ruch sprzeciwu wobec demontażu ideowego w PZPR. Była to deklaracja niezwykle istotna, gdyż na początku czerwca BP KC PZPR potępiło poczynania KFP, uznając je za "szkodliwe i hamujące proces socjalistycznej odnowy" oraz "spychające partię na boczne tory". Po tak zdecydowanej i ostrej reprymendzie forum katowickie postanowiło zawiesić działalność, ale nie poddawało się i postanowiło zwrócić się do CKKP, która pod koniec czerwca 1981 r. nie dopatrzyła się w działalności niczego nagannego ${ }^{24}$. Powołanie do życia w połowie czerwca PFK i hołd złożony przez poznańskich komunistów towarzyszom katowickim przyszły więc im w sukurs, stanowiły wsparcie dla ich walki o marksistowsko-leninowskie ideowe oblicze PZPR ${ }^{25}$. Tym bardziej, że $w$ gronie poznańskich partyjnych ortodoksów ignorowano krytyczne oceny zawarte $\mathrm{w}$ stanowisku BP. W tydzień po inauguracji działalności, na dru-

21 „Rzeczywistość” nr 7, 5 lipca 1981 r.

22 J. Kazimierski, dz. cyt., s. 212 i n.

23 "Gazeta Poznańska” nr 120, 22 czerwca 1981 r.

${ }^{24}$ J. Kazimierski, dz. cyt., s. 221-224.

${ }^{25}$ Archiwum Akt Nowych (AAN), KC PZPR, sygn. XI/1303, k. 3-5. List uczestników Katowickiego Forum Partyjnego do uczestników Poznańskiego Forum Komunistów z 2 lipca 1981 r., w którym pisano m.in.: „[...] z ogromnym uznaniem i nadzieją odebraliśmy wiadomość o aktywizacji sił marksistowsko-leninowskich w wojewódzkiej organizacji partyjnej Poznania i powołaniu do życia Poznańskiego Forum Komunistów. [...] W pełni popieramy Wasze stanowisko wyrażone z rezolucji z dnia 16 czerwca 1981 r. [...] Dążąc do odrodzenia partii i obrony socjalizmu zagrożonego przez elementy kontrrewolucyjne i oportunistyczne [...] podobnie jak i Wy przyszłość PZPR i socjalizmu w naszym kraju widzimy wyłącznie w kategoriach niepodważalnej wierności zasadom marksizmu-leninizmu, proletariackiego internacjonalizmu". 
gim posiedzeniu PFK nie omieszkało sformułować pod adresem delegatów na wojewódzką konferencję i zjazd PZPR swoich oczekiwań, które sprowadzały się do przesłania, iż „zajmą stanowisko wobec coraz śmielej i perfidniej działających sił antysocjalistycznych i kontrrewolucyjnych, mających na celu zmianę ustroju socjalistycznego i wyrwanie Polski Ludowej z grona państw socjalistycznych" 26 .

Na konferencji wojewódzkiej, która obradowała w przededniu obchodów poznańskiego buntu 1956 r. (24-25 czerwca 1981 r.) i wyłoniła nowe władze PZPR w Poznaniu, te argumenty nie mogły zyskać poparcia delegatów, były zbyt jednostronne, by nie powiedzieć prostackie. Toteż nic dziwnego, że spotkały się z repliką. PFK zaatakował uczestnik reprezentujący PFMP, robotnik z Wiepofamy Alfred Koch. Podkreślił, że w przeciwieństwie do reprezentowanego przez niego forum, które jest społecznym i spontanicznym ruchem na rzecz ożywienia partii, kontrastującym z pogrążonym w zastoju KW. Pytał retorycznie: „,[...] czyżby poparcie towarzyszy z Komitetu Wojewódzkiego dla anonimowej i niejako konspiracyjnej inicjatywy osób, których część figuruje w rejestrach IX Zespołu Zjazdowego, miało zastąpić program pracy ideologicznej i propagandowo-agitacyjnej wojewódzkiej organizacji partyjnej?" I wskazywał na dość, jego zdaniem, czytelną zbieżność: powołanie na krótko przed konferencją PFK ", to chęć manipulowania delegatami" ${ }^{27}$. Zarzuty te usiłował odeprzeć stojący na czele PFK Jan Majerczak. I nie odmawiał wprawdzie konkurentom z PFMP zasług, doprowadzili bowiem do ożywienia życia wewnątrz partii, ale - jak akcentował - „od kilku [...] miesięcy obserwujemy zmasowany napór wrogich sił, które wychodząc z różnych pozycji ideowych i politycznych zmierzają do jednego celu: rozbicia jedności naszej partii, jej ideologicznego rozbicia, uczynienia partii niezdolnej do odgrywania przewodniej roli"28. Pozwoliłem sobie przytoczyć fragmenty wystąpień obu wypowiedzi, gdyż nie były one tak jednoznaczne i krytyczne, jak to przedstawiono nazajutrz $\mathrm{w}$ sprawozdaniu zamieszczonym $\mathrm{w}$ miejscowym organie $\mathrm{PZPR}^{29}$. Na konferencji dało się zauważyć, iż spór między obu forami wśród

${ }^{26}$ Stanowisko Poznańskiego Forum Komunistów z 22 czerwca 1981 r. patrz: „Gazeta Poznańska" nr 122, 24 czerwca 1981 r.

${ }^{27}$ APP, KW PZPR, sygn. 26, k. 130-131.

${ }^{28}$ Tamże, k. 134.

${ }^{29}$ Warto zwrócić uwagę na relację z konferencji, która pojawiła się na łamach organu KW PZPR w Poznaniu („Gazeta Poznańska” nr 124, 26/ 28 czerwca 1981 r.), w dość istotny bowiem sposób odchodzi ona od przebiegu obrad odnotowanego w stenogramie (APP, KW PZPR, sygn. 26), dotyczy to kolejności wystąpień i wniosków, które znalazły się w zamieszczonym materiale prasowym. Przekaz dziennikarski rządzi się, rzecz jasna, swoimi prawami, musi być bardziej zwięzły, ale i oddawać istotę wypowiedzi dyskutantów. Nie sposób też wykluczyć, że uciekając się do pewnej nadinterpretacji, którą zawarto w sprawozdaniu poznańskiego organu partii, iż w sposób przejaskrawiony miała oddać istotę kontrowersji i zarazem artykułowała krytyczną ocenę, co wyrażało opinię redakcji, która raczej wspierała liberalne skrzydło w PZPR 
większości delegatów nie budził większych emocji. Górę brała chęć szukania kompromisu i unikania sporów, zachęcano wręcz, aby oba obozy się połączyły. Reprezentujący organizację partyjną w HCP Stanisław Kałkus, późniejszy członek BP PZPR, uznał, iż bardziej sensownym rozwiązaniem (niźli, jego zdaniem, owe jałowe spory ideowe) byłoby utworzenie Forum Myśli Gospodarczej, a więc gremium zajmującego się proponowaniem rozwiązań problemów, które najbardziej doskwierają społeczeństwu ${ }^{30}$. I na nic się zdała bardzo krytyczna opinia o PFK, którą sformułował w swoim liście do uczestników konferencji prof. Wacław Wilczyński. W jego opinii PFK jest wąską grupą, która unika wystąpienia z otwartą przyłbicą, tym samym - jak twierdził naukowiec - „uczestnicy tego Forum, nie zdali egzaminu z odwagi cywilnej, co eliminować ich powinno automatycznie z życia partii". Odnosząc się do uchwały PFK, podkreślił, iż „obok spostrzeżeń słusznych, zawierała [ona] treści bałamutne i szkodliwe”. Bo przecież - jak dowodził - „tylko ludzie zupełnie pozbawieni wiedzy ekonomicznej mogli dojść do wniosku, że błędy gospodarcze z ubiegłego 10-lecia są wyolbrzymione". Nie omieszkał ich wymienić i choć jego słowa nie brzmią dziś oryginalnie czy nawet nie są trafne, to jednak wówczas celnie zbijały argumenty ortodoksów ${ }^{31}$. Co jednak istotniejsze, w toczonej wówczas dyskusji prof. Wilczyński zauważył, że „[...] rozbrojenie ideologiczne następowało od góry, a nie na skutek nadmiernego liberalizmu politycznego. Kierownictwo partii nie miało bowiem moralnej legitymacji do walki z opozycją wewnątrz i pozapartyjną, jego wyjątkowo niski poziom intelektualny nie tylko powodował błędne decyzje, lecz stanowił pożywkę dla satyryków i krytyków. Kierownictwu służył natomiast bezkrytycznie terenowy aparat władzy pogłębiając przepaść między partią a masami”. I konkludując, podkreślił: „[...] uchwała Poznańskiego Forum Komunistów z braku rzeczowych argumentów uderza w ton[y] dobrze nam znanych z przeszłości. Tak, jak po roku 1968 ośmieszano, szkalowano, a nawet niszczono »naprawiaczy« socjalizmu, tak teraz uchwała Poznańskiego Forum Komunistów »opatruje« odnowicieli. Dla każdego czytelnika tej uchwały jest oczywistym, że wydziera z niej zwykły zamordyzm, jako sub-

i tym samym nie kryła swego dystansu do PFK. Na tej ocenie oparł się także Z. Czerwiński, Walka o komitet, „Przegląd Poznański” 1988, nr 1, s. 10; autor, opierając się na informacji poznańskiego organu partii, pisał, iż to Majerczak - wskazując na PFMP jako przyczynę wszelkiego zła - zaatakował siły rozbrajające PZPR ideologicznie i organizacyjnie, co spotkało się ze zdecydowaną odpowiedzią ze strony PFMP w osobie Alfreda Kocha, który miał stwierdzić wprost, że partii szkodzą właśnie „związane z broniącym swych partykularnych interesów mafijne struktury jak PFK".

${ }^{30}$ APP, KW PZPR, sygn. 26, k. 208

${ }^{31}$ Wilczyński do błędów wówczas popełnionych zaliczył całkowite zrujnowanie planowego charakteru gospodarki $\mathrm{w}$ pierwszej połowie lat siedemdziesiątych (APP, KW PZPR, sygn. 26, k. 161). 
stytut rozumu i demokracji, jako gwarancja »spokojnego« sprawowania nieograniczonej władzy, władzy nie pochodzącej od ludu". List Wilczyńskiego, który odczytał jeden z liderów PFMP i I sekretarz KU PZPR w UAM Michał Karoński, miał być ważkim argumentem przeciwko wyborowi tych, którzy odwołując się do komunizmu, nie są zdolni przezwyciężyć kryzysu partii, katastrofy gospodarczej, a jedynie prą do odzyskania władzy i tym samym powrotu do „skompromitowanego systemu kierowania" ${ }^{32}$.

Ciekawym elementem świadczącym nie tylko o rozziewie między zasadami wyznawanymi przez przedstawicieli PFMP a PFK było odwołanie się przez grupę Majerczaka do komunizmu. Koch pytał: „[...] jakim prawem grupa osób przywłaszczyła sobie termin komunisty, odnosząc go wyłącznie do siebie i wybranych przez siebie ludzi"33? Odpowiedział mu Majerczak: „[...] w obecnej sytuacji politycznej w naszym kraju nie każdy chce się do końca określić komunistą [...] to słowo jest moim zdaniem wielkim wyróżnienie$\mathrm{m}^{\prime \prime 34}$. Przez niektórych wiernych zasadom partyjnej ortodoksji, ale niezwiązanych z PFK, potraktowane to zostało jako próba zawłaszczenia i przyznania sobie wyłączności do miana bycia komunistą. Wprawdzie do komunizmu odwoływano się w PRL werbalnie w sposób bezrefleksyjny, niejako bezwiednie traktując tego typu słowa jako pustą, niewiele znaczącą deklarację, ale po 1980 r. można mówić o rosnącym dystansie do utożsamiania się z tą ideologią. Spór, do jakiego doszło w czasie czerwcowej konferencji w Poznaniu, był tego wymownym dowodem. Wtedy Tadeusz Rajewicz, ślusarz w Fabryce Maszyn Żniwnych w Poznaniu i jednocześnie szefujący działającej tam OOP PZPR, stwierdził wręcz: „,[...] operowanie określeniem komunista u niektórych towarzyszy naszej partii jest upokorzeniem, jako robotnika [...] nadszedł wreszcie czas, by wreszcie powstał program [...] szacunku dla ludzi pracy i wspólnego działania ze związkiem zawodowym, a szczególnie z »Solidarnościąu, bo jest w tym związku ogromna większość klasy robotniczej, członków Polskiej Zjednoczonej Partii Robotniczej"35. Ta deklaracja, będąca swego wyrazu aktem dystansu części członków PZPR do ciągle jeszcze głoszonych ideowych zaklęć, przez część obecnych mogła zostać potraktowana za akt apostazji i niewykluczone, że wpłynęła na decyzje delegatów czerwcowej konferencji PZPR w Poznaniu, a później również tych, którzy podczas nadzwyczajnego zjazdu partii w Sali Kongresowej nie odważyli się na dokonanie radykalnego zwrotu. Oczywiście, inną sprawą jest, czy w ówczesnej konstelacji geopolitycznej był on w ogóle możliwy. Tu warto jednak zauważyć, że w okresie Solidarnościowej rewolucji dokonał się także pewien „prze-

\footnotetext{
${ }^{32}$ APP, KW PZPR, sygn. 26, k. 160-163.

${ }^{33}$ Tamże, k. 130.

${ }^{34}$ Tamże, k. 140.

35 Tamże, k. 158-159.
} 
wrót semantyczny" dotyczący znaczenia słów traktowanych dotąd za oczywiste i neutralne, a teraz nabierające negatywnej konotacji ${ }^{36}$. Do nich należały słowa „komunizm” i „komunista”, które zaczynały wówczas znaczyć pejoratywnie, do czego w niemałym stopniu przyczynili się afiszujący się nimi „twardogłowi” w PZPR, kojarzeni powszechnie ze zdeklarowanymi przeciwnikami reform $\mathrm{i}$ „,odnowy".

Izolując się, nie mieli jednak odwrotu. Również poznańscy "twardogłowi" postanowili nie składać broni. Na kolejnym, trzecim spotkaniu PFK, które odbyło się 1 lipca - po wprowadzającym referacie prof. Józefa Boronia z poznańskiej Akademii Ekonomicznej - dyskutowano o reformie gospodarczej oraz przyjęto deklarację zatytułowaną Za jaka odnowa jesteśmy? ${ }^{37}$ Nie wszyscy jednak podzielali przekonanie, iż towarzyszom skupionym w PFK rzeczywiście na sercu leży powrót PZPR do „prawdziwie lewicowych” korzeni. Jan Brygier, przedwojenny działacz komunistyczny, wyraził przekonanie, że za Majerczakiem chowają się byli prominentni działacze partyjni i urzędnicy, którzy utracili swe stanowiska ${ }^{38}$. Ten pogląd wydaje się jednak tylko częściowo zasadny, zważywszy, iż aktywnie w jego działalność włączył się choćby prof. Boroń, którego trudno uznać za „byłego prominenta” ${ }^{39}$. W jego kręgu znaleźli się więc także ludzie wierni idei komunistycznej, którzy w posierpniowej rzeczywistości nie potrafili się po prostu odnaleźć. Wiele jednak przemawia za tym, że w PFK wiodącą grupę stanowili młodsi partyjni aparatczycy, którzy utraciwszy stanowiska i wpływy, a usiłując je odzyskać taktycznie

${ }^{36}$ Por. A. Wierzbicka, Jezzyk antytotalitarny w Polsce: o pewnych mechanizmach samoobrony jezykowej, „Teksty Drugie: teoria literatury, krytyka, interpretacja” 1990 , nr 4, s. 27; która pisze o transformacji tych kluczowych pojęć w czasie „erozji strachu”, a więc w okresie posierpniowym.

${ }^{37}$ O tym zdawkowo poinformował jedynie „Express Poznański” nr 126, 2 lipca 1981 r., w którym na próżno szukać informacji o przyjętej wówczas deklaracji.

38 APP, KW PZPR, sygn. 492, k. 8. Taką opinię Brygier sformułował podczas posiedzenia egzekutywy KW 29 lipca 1981 r. i wskazał na pozbawionych swych stanowisk Stanisława Wojdacza (sekretarza Jerzego Zasady) i Bogusława Boczarskiego (dyrektora Wydziału Komunikacji Urzędu Miejskiego). I nie był to bynajmniej pogląd odosobniony, patrz: wystąpienie Ireny Bajońskiej-Wojtkowiak (I sekretarz KMG w Nowym Tomyślu) na plenum KW PZPR 6 sierpnia 1981 r.; APP, KW PZPR, sygn. 163, k.157/158; Czerwiński, nie przywołując źródeł, określił Majerczaka „przybocznym Tadeusza Grabskiego” i pisał, że w tym kręgu znaleźli się także m.in. Stanisław Cozaś i prof. Feliks Siemieński; patrz: „Przegląd Poznański” 1988, nr 1, s. 9. Brygier w swoich wspomnieniach Trudne lata 1980-1984, s. 30, pisze, iż Majerczak wiele razy zwracał się do niego „,...] jako zasłużonego działacza partyjnego z dopiskiem: głos towarzysza może być cennym dla [...] sprawy. Ale nigdy nie brałem udziału w ich zebraniach. Przychodziło tam bardzo mało ludzi. Przeważali ci, którym stawiano zarzuty, byli prominenci. Jednak uczciwe muszę przyznać, że wówczas takich zarzutów wobec Jana Majerczaka nie stawiano".

${ }^{39} \mathrm{O}$ politycznym zaangażowaniu prof. Boronia nie wspominają Sz. Cyfert, K. Krzakiewicz, Wspomnienie o profesorze J. Boroniu, „Organizacja i Kierowanie” 2011, nr 1(144), s. 7-9. 
wspierali, by nie powiedzieć posłużyli się J.Majerczakiem. I to poznańskich „twardogłowych" dość istotnie różniło od katowickich współtowarzyszy walki, w większości działaczy starszej generacji, mocno przywiązanych do swojego ideowego dogmatycznego rodowodu, w których deklaracjach niejednokrotnie pobrzmiewały stalinowskie nuty ${ }^{40}$.

Nadzwyczajny zjazd PZPR (14-20 lipca) nie rozwiał jednak wątpliwości ani oskarżeń formułowanych pod adresem grup reformatorskich, gdyż w nowo wybranych władzach zabrakło tam choćby działaczy ich wspierających. Nadto dość jednoznacznie potępił przejawy działań dogmatycznych, zmienił także regulacje statutowe, które niedwuznacznie zabraniały działań o charakterze frakcyjnym ${ }^{41}$. Zapewne to skłoniło nowe władze partyjne w Poznaniu, aby zażądać od PFK dowodów, że jego działalność cieszy się poparciem statutowych struktur PZPR. Takich jednak deklaracji poparcia PFK nie przedstawiło, co nie dziwi, zważywszy - co już wspomniano że PFK było grupą bardzo nieliczną: Majerczak z dumą mówił, iż skupia ok. 150 osób $^{42}$, a więc cieszyło się zdecydowanie mniejszym zapleczem od PFMP. I to sprawiło, że wojewódzkie kierownictwo partii oznajmiło, że „nie będzie afirmować [jego] działalności" ${ }^{\prime 3}$. Ale to nie skłoniło ich do jej zaprzestania, wręcz przeciwnie - poznańscy komuniści postanowili „uciec do przodu”.

A zatem niewykluczone, że demonstrowana pryncypialność i ignorowanie $\mathrm{w}$ kręgu poznańskich twardogłowych przestróg płynących zarówno z centrali partyjnej w Warszawie, jak i miejscowego KW, sprawiły, iż to właśnie oni podjęli się zorganizowania konferencji konsultacyjnej działających w kraju grup nieakceptujących zmian dokonujących się w PZPR. 28 lipca 1981 r. zebrali się w Poznaniu przedstawiciele kilkunastu już istniejących organizacji oraz kilku tworzących się komórek odwołujących się do tradycji komunistycznej, gotowych do obrony przed tendencjami socjaldemokratycznymi w partii. „Cel spotkania, które nas mimo różnych nazw łączy - jak podkreślił otwierający je Majerczak - jest jeden: stworzenie klimatu aby nasza partia pozostała marksistowska". A to właśnie, jak dowodził w referacie wprowadzającym główny ideolog forum katowickiego Wsiewołod Wołczew, po ostatnim nadzwyczajnym zjeździe PZPR jest bliskie, gdyż ofensywa lewi-

${ }^{40}$ Por. P. Gasztold-Seń, Dogmatyczna fronda w PZPR. Dziatalność Katowickiego Forum Partyjnego w roku 1981, [w:] Elity komunistyczne w Polsce. Warszawa-Lublin 2015, s. 366 i n.

${ }^{41}$ J. Kazimierski, dz. cyt., s. 225 i n.

${ }^{42}$ APP, KW PZPR, sygn. 26, k. 137.

${ }^{43}$ Na posiedzeniu plenum KW PZPR, które obradowało 6 sierpnia 1981 r., Skrzypczak podkreślił, że PFK „,[...] otrzymało polecenie przedstawienia uchwał podstawowych organizacji partyjnych, względnie egzekutyw [...] sankcjonujących ich działalność. W przypadku jeśli takie uchwały nie będą przedstawione, nie uznajemy ich działalności, nie pozwolimy na tego rodzaju poczynania pod szyldem Komitetu Wojewódzkiego, czy instancji partyjnych. Po raz ostatni zwróciłem się w tej sprawie do przewodniczącego Forum, bodajże przed tygodniem [...]". 
cy i poparcie bratnich partii zahamowały „siły prawicy, osłabiło siły antysocjalistyczne i kontrrewolucyjne, dzięki temu plany prawicy na zjeździe nie mogły się ziścić. Prawica zmobilizowała przed zjazdem struktury poziome, aparat partyjny, prasę i przy pomocy Solidarności mogła powiedzieć zjazd jest nasz, ale nic z tego nie wyszło. Kadrowo prawica poniosła na zjeździe klęskę, jej przedstawiciele są zdegustowani i zdezorientowani. Lewica też poniosła istotną klęskę, ale tu został pewien krok zrobiony". Jednak, jak podkreślił Wołczew, „partia jest $\mathrm{w}$ defensywie [...] dopóki jesteśmy przy instancji możemy na nie oddziaływać, to istotne bo odpieramy tym zarzuty o frakcyjność”. I dodawał, że „bazą ruchu powinny być zakłady pracy”, ale zaznaczył, że "ze względów taktycznych trzeba przekształcić się w seminaria marksistowsko-leninowskie przy komitetach". Kończąc swe wystąpienie, lider KFP z optymizmem mówił, iż należy pracować nad programem, który winien być przedmiotem rozmów z KC PZPR. Podkreślając, iż głównym wrogiem środowisk, w imieniu których przemawiał, a więc partyjnych ortodoksów, są centryści, popadał w sprzeczność, gdyż ci przecież na zjeździe okazali się górą i zdominowali jej centralne władze ${ }^{44}$. To z góry skazywało plany, które kreślono podczas konferencji poznańskiej, na niepowodzenie. $Z$ owego braku szans na sukces całego przedsięwzięcia, a więc nadania partii „prawidłowego kursu", najpewniej zdawał sobie sprawę jej ideolog Wołczew, który na przekór apelom towarzyszy z Warszawy, wzywających do powołania krajowej konferencji komunistów polskich, zaproponował utworzenie jedynie nieformalnego zespołu konsultacyjnego, na zewnątrz nieafiszującego się tą nazwą ${ }^{45}$. Świadomość przegranej i izolacji w batalii o kształt PZPR była więc obecna wśród uczestników poznańskiej konferencji. Nie przeszkadzało to jednak niektórym jego uczestnikom przepuścić ataku na nowe władze w PZPR, z którym wystąpił biorący w niej udział Stanisław Wojdacz ${ }^{46}$. Trudno byłoby jednak oczekiwać, aby tamę kreślonemu przez uczestników spotkania niebezpieczeństwu położyć miała właśnie poznańska Konferencja Forum Komunistów Polskich. Zakończyła się przyjęciem dość mało zobowiązującego wezwania do działania na rzecz jedności partii „na linii marksizmu-leninizmu", która - nawiasem mówiąc - przez wzywających była podważana! Zdawać sobie musiano sprawę z izolowania tych dość luźno działających grup, które się w Poznaniu spotkały, gdyż skarżono się tam na „liczne przypadki szykanowania aktywistów partyjnych stojących konsekwentnie na pozycjach marksistowsko-leninowskich" ${ }^{\prime 7}$.

\footnotetext{
${ }^{44}$ AAN, KC PZPR, sygn. XI/1303, k. 6.

45 Tamże, k. 10.

46 Tamże, k. 8.

47 „Express Poznański” nr 145, 30 lipca 1981 r.
} 
W dwa dni po ogólnopolskiej konferencji zorganizowanej przez PFK zebrali się jego członkowie i sympatycy. Ponownie dano wyraz poparciu dla prawdziwego nurtu marksistowsko-leninowskiego, którego w czasie nadzwyczajnego zjazdu PZPR wyrazicielem miał być Albin Siwak. I to on właśnie, jako jego reprezentant, przeciwstawił się próbie sprowadzenia partii na pozycje rewizjonistyczne, utożsamiane z grupą Stefana Bratkowskiego i jego powiązaniami z Solidarnością. Tak więc - zdaniem omawiającego przebieg zjazdu - w PZPR uwidoczniły się nie trzy, ale dwa nurty. I w tym dychotomicznym obrazie, który jednak dość znacznie odbiegał od rzeczywistości, nie zabrakło oskarżeń o manipulację, co zdawało się osłabiać wydźwięk przegranej, jaką niewątpliwie było niepowodzenie skrzydła utożsamianego z Siwakiem. To on w oczach jednego z uczestników spotkania stał się bohaterem, jego wystąpienie zaś było wręcz „referatem programowym”, a jemu „należałoby $[. .$.$] wysłać [\ldots]$ gratulacje i pozdrowienia" ${ }^{48}$. Nie aprobowano więc decyzji ostatniego zjazdu partii, próbowano wpływać na jej rozstrzygnięcia w terenie. Stojący na czele PFK Majerczak zachęcał, aby uczestnicy propagowali cele Forum $w$ macierzystych organizacjach partyjnych i pozyskiwali tam zwolenników. Na rzecz PFK działać mieli także poza swymi organizacjami zakładowymi, pożądanym - jak podkreślał - byłoby również włączenie się $\mathrm{w}$ prace komisji problemowych działających przy KW w Poznaniu ${ }^{49}$. Ten apel, będący wezwaniem do wzmożenia aktywności w szeregach PZPR, nie mógł pozostać bez odzewu jej władz, nie był wypowiedzeniem jej posłuszeństwa, ale oznaczał, że grupa ta nie zamierzała składać broni.

Nazajutrz po konferencji poznańskiej ostro zareagowały władze partyjne w Katowicach, które zalecały zawieszenie KFP. W podobne tony uderzył I sekretarz w Poznaniu Edward Skrzypczak, który w czasie plenum KW PZPR 6 sierpnia 1981 r. stwierdził niezbyt precyzyjnie, iż miejscowe kierownictwo partyjne „przestanie afirmować” poczynania $\mathrm{PFK}^{50}$.

Niebawem, 11 sierpnia, podczas II plenum KC jeszcze ostrzej ten nurt w partii zaatakował członek Biura Politycznego KC PPZR Kazimierz Barcikowski, stwierdzając, że „naraża [on] partię na chorobę frakcyjności” i zagroził wyciągnięciem konsekwencji przewidzianych w statucie. Te groźby podziałały dyscyplinująco na komunistów w Katowicach, którzy na swo-

${ }^{48}$ Jej przejawem miało być nie tylko późne udzielenie głosu Siwakowi, ale również wystąpienie Mieczysława Rakowskiego, który opowiedział się „przeciwko linii St. Kani i przygotowywał się do przejęcia władzy", oraz przystąpienie do wyborów władz wkrótce po referacie Kanii a nie pod koniec zjazdu. Takie oskarżenia sformułował relacjonujący przebieg zjazdu jego uczestnik (w charakterze gościa) Ryszard Rosa; patrz: „Gazeta Poznańska” nr 150, 3 sierpnia $1981 \mathrm{r}$.

${ }^{49}$ Tamże.

${ }^{50}$ Z kontekstu wypowiedzi wynikało, że przestanie tolerować działalność PFK; patrz: APP, KW PZPR, sygn. 163, k. 156. 
im ostatnim spotkaniu 29 września postanowili przekształcić się w mniej sformalizowaną grupę, którą - jak w Poznaniu zalecał Wołczew - nazwano Seminarium Marksistowsko-Leninowskim. Choć obniżało to nieco organizacyjną hierarchię, jednak w dalszym ciągu wyrażało dystans do zmian, które nastąpiły w $\mathrm{PZPR}^{51}$. Na ten sam krok zdecydowało się PFK, które podążyło podobnym śladem. Jednak coraz bardziej izolowane, szukało sojusznika, a tym mógł być jedynie tolerowany jeszcze w PZPR ruch skupiony wokół tygodnika „Rzeczywistość".

Decyzje zjazdu wymierzone w działalność frakcyjną oraz dość zdecydowana reakcja centralnych i regionalnych władz partyjnych spacyfikowała oba skrzydła w PZPR. Zmierzający do odnowy w duchu socjaldemokratycznym podporządkowali się woli większości. Z powodu braku źródeł nie sposób ustalić, kiedy zostały podjęte decyzje o zaprzestaniu działalności przez oba przeciwstawne gremia. Wszystko na to wskazuje, że w pierwszej połowie października, co z zadowoleniem odnotowały władze partii w Poznaniu, gdzie na plenum KW (19 października 1981 r.) uchwalono formy dyskusji ideowych $\mathrm{w}$ partii, co była konsekwencją decyzji podjętych już wcześniej w Warszawie ${ }^{52}$.

Natomiast grupa związana tygodnikiem „Rzeczywistość”, zabiegająca o względy środowisk "patriotycznych" w partii i wspierająca ortodoksów, ciągle korzystając z parasola ochronnego na szczytach władzy - nie zamierzała się poddawać. Przystąpiono do tworzenia struktur zrzeszających czytelników tego pisma, co zainicjowano we wrześniu w Łodzi. W Poznaniu animatorem klubu skupiającego zwolenników „Rzeczywistości” miał być prof. Antoni Czubiński, a do jego powstania doszło na początku listopada 1981 r. ${ }^{53}$ Co jednak znamienne, on sam się z tej inicjatywy wycofał, gdyż jak podkreślił, mimo że je wcześniej wspierał (także publikując na jego łamach), obecnie „pismo to podejmuje krytykę różnych zjawisk z pozycji sekciarskich, co nie służy konsolidacji partii" ${ }^{54}$. Co zatem sprawiło, że się od tego pomysłu

${ }^{51}$ J. Kazimierski, dz. cyt., s. 229.

${ }^{52}$ Choć brakuje dowodów, aby była to decyzja bezpośrednio wymuszona przez KW w Poznaniu, jednak wszystko wskazuje na to, że tak presja władz, jak i sytuacja do takiego właśnie rozstrzygnięcia obie grupy skłoniła. Na posiedzeniu egzekutywy KW 18 października jej członek Jan Mielcarek oznajmił, że PFK „przestało funkcjonować jako samodzielna organizacja, poza strukturą Komitetu Wojewódzkiego", patrz: APP, KW PZPR, sygn. 493, k. 72.

53 "Głos Wielkopolski" nr 220, 9 listopada 1981 r.

54 "Głos Wielkopolski” nr 223, 12 listopada 1981 r.; nie dysponując materiałami źródłowymi, ale mając na uwadze jego zdystansowanie się od tej inicjatywy, można jedynie domniemywać, że Czubiński bardziej firmował niż rzeczywiście stał za powołaniem klubu „Rzeczywistości” w Poznaniu. Tym samym, uwzględniając cały kontekst, za jego animatora uznać można Majerczaka, który aktywnie brał udział w zebraniu założycielskim i został członkiem jego rady programowej. 
zdystansował? Po nadzwyczajnym zjeździe PZPR, na którym klęskę ponieśli zarówno przedstawiciele skrzydła reformatorskiego, jak i reprezentanci partyjnego „betonu”, los tworzonych przez nich struktur został w zasadzie przesądzony. Nawet w Poznaniu, gdzie I sekretarzem KW został popierany przez struktury poziome Skrzypczak, ich czołowym przedstawicielom on sam wyraźnie dawał do zrozumienia, iż winni się podporządkować statutowym władzom partii ${ }^{55}$.

Powołana przez Majerczaka struktura wewnątrz partii nie odegrała większej roli (bo nie mogła), była swoistą koterią, inicjatywą wąską i izolowaną, a nadto ofertą skierowaną do nielicznych środowisk, gdyż w PZPR pod olbrzymią presją powszechnego poparcia robotników dla Solidarności nie było już powrotu do stanu, za którym tęsknili partyjni ortodoksi. Dobitnie wyraził to były I sekretarz komitetu powiatowego w Koninie Kazimierz Lamprycht, który w listopadzie 1981 r. wprost zarzucił Majerczakowi, że jego działalność ma charakter sekciarski i w swym zaślepieniu zmierza do podziału w partii „na różne orientacje i frakcje” ${ }^{56}$. Abstrahując od tych sformułowań, które sięgają do słownika inwektyw czasów, kiedy w partiach komunistycznych rozprawiano się z nieprawomyślnymi działaczami, to nie ulega wątpliwości, że frakcja twardogłowych przestała być w PZPR użyteczna. Jej dogmatyzm nie przystawał do czasów, w jakich aparat PZPR musiał walczyć o zachowanie swej dominującej pozycji.

Choć także na prowincji dały się słyszeć głosy, że „działając dalej wg. polityki dyskusji i ustępstw doprowadzimy do tego, że z partii marksistowskiej przemienimy się $\mathrm{w}$ partię reformatorską [reformistyczną] - partię opartą na ideologii drobnomieszczańskiej"57 - to jednak nie one brzmiały najgłośniej. Poza stolicą Wielkopolski jedynie w Lesznie zawiązała się grupa, która chciała podążyć śladami towarzyszy z Poznania ${ }^{58}$.

Większość pogrążyła się w marazmie, co w liście do ówczesnego wicepremiera Mieczysława Rakowskiego (pod koniec października 1981 r.), w bardzo alarmistycznym tonie opisywał wspomniany wcześniej Kolasiński: „Jest wszechobecna, totalnie obezwładniająca wszystkich rezygnacja z walki o partię walczącą, jaka miała powstać po IX Nadzwyczajnym Zjeździe. Gdybym potrafił rysować jak Szymon Kobyliński, to obecną sytuację przedstawiłbym następująco: rząd PRL, to inwalida na wózku popychanym przez mizernego

${ }^{55}$ Relacja Jana Dutko, aktywnego w strukturach poziomych, a później pracownika KW PZPR w Poznaniu.

${ }^{56}$ APP, KW PZPR, sygn. 1232, k. 85 (List otwarty Kazimierza Lamprychta z 14 listopada 1981 r.).

57 Tamże, sygn. 1673, k. 102 (Opinia KMG z Nowego Tomyśla z 15 lipca 1981 r.).

${ }^{58}$ W poznańskiej konferencji z udziałem komunistycznych klubów z całej Polski, która została zorganizowana pod koniec lipca 1981 r., wzięła udział formująca się grupa z Leszna; patrz: „Gazeta Poznańska” nr 148, 30 lipca 1981 r. 
człowieczka z napisem PZPR. Ten żałosny kondukt popędza w sobie tylko wiadomym kierunku głupawy osiłek »Solidarność", trzaskający biczem symbolizującym strajk. Przepraszam, że piszę tak do wicepremiera, który usiłował dogadać się z owym osiłkiem, któremu Bozia dała siłę, ale poskąpiła rozumu" 59 .

I tylko u części co bardziej światłych i zaangażowanych w "odnowę" działaczy PZPR górę brało przekonanie, że szansą jest ucieczka do przodu, a więc jej różnie pojmowana reforma, nie zaś reanimacja ideologicznej ortodoksji. Jednak i oni niewiele byli w stanie zmienić, gdyż trwającą $\mathrm{w}$ marazmie i biurokratycznym kleszczach partię nie potrafiły z tego stanu wyrwać zmiany, choć nie tak dogłębne, jak chcieli reformatorzy, gdyż przemiany zablokowali przestraszeni ich konsekwencjami „realiści”, do tego doszło właśnie (również) w Poznaniu. Tam I sekretarzem został wprawdzie wysunięty przez nich Skrzypczak, ale ze skupionego wokół niego grona optujących za głębszymi przeobrażaniem PZPR mało kto do jej statutowych władz został wybrany. Toteż mimo przeprowadzonej czystki w samym aparacie, nawet $\mathrm{w}$ poznańskiej PZPR zmieniło się niewiele ${ }^{60}$. A więc tylko zdecydowana mniejszość chciała wrócić do źródeł, werbalnie do fundamentalnych zasad, bardziej do odzyskania wpływów, czego pragnęli także ludzie skupieni w PFK. Byli w PZPR marginesem, ich liczebność szacować można na zaledwie kilka procent ${ }^{61}$. I to również świadczyło o głębokości kryzysu, w jakim znalazła się PZPR.

Z tego kryzysu usiłowali się wyrwać najbardziej zdeterminowani działacze partyjnych młodzieżowych przybudówek, a więc ZSMP i SZSP, które w czasie sierpniowego kryzysu okazały się organizacjami fasadowymi, gdyż wielu z ich członków wstąpiło do Solidarności bądź wsparło nową organizację studencką, czyli NZS. Choć zdarzali się bardzo nieliczni młodzi, którzy na przekór zdecydowanej większości zorganizowanej w ZSMP aktywnej politycznie młodzieży poparli Solidarność - wybrali drugą stronę barykady i sięgając do głębokiej przeszłości polskiego ruchu komunistycznego, zdecy-

${ }^{59}$ M. Kolasiński, dz. cyt., s. 12-13.

${ }^{60}$ Tkwiący w nim od kilkunastu lat Kolasiński pisał: „W 1981 roku w poznańskim KW PZPR wymieniono na nowych niemal wszystkich pracowników politycznych. Czyniono to z nadzieją zmiany stylu i metod pracy partyjnej, tak krytycznie ocenianej wielokroć w latach poprzednich i podczas wydarzeń zapoczątkowanych Sierpniem'80. Sporej części aparatu partyjnego bliskie były idee rodzącej się »Solidarności«. Wymianie pracowników, także ludzi we władzach partyjnych, nie towarzyszyła jednak zmiana doktryny, celów programowych ani procedur i nawyków biurokratycznych. Nowi ludzie weszli w stare koleiny, wszystko potoczyło się po staremu. Czas jakiś nowe walczyło ze starym, ale w końcu padło zmęczone pod naporem rygorów służbowych i wymogów subordynacji"; M. Kolasiński, dz. cyt., cz. IV, Poznań 2009, s. 50.

${ }^{61}$ E. Duraczyński, dz. cyt., s. 85-86. 
dowali się powołać do życia Komunistyczny Związek Młodzieży Polskiej. Organizacja zawiązała się na początku 1981 r. w obliczu coraz bardziej widocznego rozpadu PZPR oraz kontrolowanego przez nią SZMP. Inicjatywa ta zrodziła się $\mathrm{w}$ środowisku studenckim, gdzie tradycje związane $\mathrm{z}$ „młodą gwardią" polskiego ruchu komunistycznego były nie tyle żywe, co jak można przypuszczać - dla nielicznej grupy stanowiły bardziej historyczno-nostalgiczne wspomnienie ${ }^{62}$. Z inicjatywą tą wystąpiono w kilku miejscach, pierwsi (25 marca 1981 r.) byli młodzi ludzie w Katowicach, którzy utworzyli Związek Młodzieży Komunistycznej, tydzień później (2 kwietnia) w ich ślady poszli koledzy z Warszawy, swej organizacji nadając już tradycyjną nazwę Komunistyczny Związek Młodzieży Polskiej. Podobnie kilka tygodni później postąpili młodzi komuniści w Łodzi, gdzie też 10 czerwca KZMP został formalnie zarejestrowany $\mathrm{w}$ tamtejszym Urzędzie Miejskim. Choć różnorodność tych inicjatyw wskazuje raczej na to, iż nie była to akcja skoordynowana i sterowana z zewnątrz, jednak niewątpliwie inspirowana była ideologicznie i cieszyła się wyraźnym poparciem twardogłowego kręgu w centralnych władzach PZPR (Tadeusz Czechowicz, Albin Siwak i Stefan Olszowski) ${ }^{63}$. Po rejestracji KZMP nie mogła się poszczycić większym poparciem, o czym zdaje się świadczyć wątłość jej struktur terenowych ${ }^{64}$. Powstało ich bowiem ledwo kilka, w tym Komitet Okręgowy z siedzibą w Poznaniu, którym kierował Paweł Neyder ${ }^{65}$. W kręgach partyjnej biurokracji inicjatywę tę skwitowano z pewnym lekceważeniem, dało się tam usłyszeć: „[...] ubrali się w skórzane kurtki i wydaje im się, że są bolszewickimi komisarzami z okresu rewolucji; że krytykują nas z lewej strony, a do niczego nam się nie przydadzą, bo i tak jest ich za mało"66.

${ }^{62}$ T. Junes, Student Politics in Communist Poland: Generations of Consent and Dissent, Lanham 2015 , s. 200. Warto wspomnieć, że pierwsze tego rodzaju inicjatywy pojawiły się na krótko przed sierpniem 1980 r. w środowisku studenckim w Krakowie, gdzie w czerwcu zawiązał się Komunistyczny Związek Studentów, patrz: P. Darczewski, Trzeba jutrem żyć, „Rzeczywistość” nr 28, 29 listopada $1981 \mathrm{r}$.

${ }^{63}$ Z. Wiktor, Komunistyczny ruch młodzieżowy w Polsce, [w:] Młode pokolenie Polski, red. B. Rogowska, Wrocław 2000, s. 147, 150.

${ }^{64}$ Zamiarem założycieli KZMP nie było stworzenie organizacji masowej, miała być inicjatywą o charakterze kadrowym, patrz: P. Darczewski, dz. cyt.

${ }^{65}$ Podział ten dokonany został 25 sierpnia 1981 r. decyzją Komitetu Krajowego KZMP, Okręg z siedzibą w Poznaniu obejmował wprawdzie województwa: poznańskie, konińskie, leszczyńskie i kaliskie, ale na próżno szukać (poza poznańskim) śladów aktywności tej organizacji.

${ }^{66} \mathrm{Z}$ referatu Michała Chmary podczas plenum KD poświęconego sprawom młodzieży, patrz: „Kontakty. Biuletyn” nr 7 [KD PZPR Poznań-Stare Miasto]; w informacji sporządzonej na polecenie członka BP Kazimierza Barcikowskiego znalazła się podobna konkluzja, która sprowadzała się do stwierdzenia, że KZMP „uznający przywództwo i linię polityczną partii pozostający jednak elitarnym ruchem intelektualnym bez realnych wpływów wśród młodzie- 
Twórcy KZMP nie kryli, że ich inicjatywa wymierzona jest przeciwko „oportunizmowi, rewizjonizmowi i kontrrewolucji”, ale nie omieszkali także podkreślić, iż „ideowe założenia naszego ruchu tożsame są z zasadami zawartymi w statucie PZPR z którą jesteśmy ideowo związani. Popieramy oddolny ruch w partii dążący do jej demokratyzacji ograniczenia dominacji biurokratycznego aparatu partyjnego. Opowiadamy się też za jednością partii i działać będziemy przeciwko dążeniu do jej frakcyjnego rozbicia" ${ }^{\prime 67}$.

Należy wątpić, aby ideowa i historyczno-nostalgiczna inspiracja, która legła źródeł powstania pierwszych organizacji KZMP, stanowiła natchnienie młodych ludzi lewicy w terenie. Tam najpewniej motywował ich do działania rozkład fasadowych struktur ruchu młodzieżowego, którego członkowie w większości zasilili ruch solidarnościowy. Na taki bez wątpienia demonstracyjny krok zdecydowało się jedenastu młodych, w większości członków ZSMP w Wałczu ${ }^{68}$. I ta lokalna inicjatywa zdaje się potwierdzać, iż ruch ten miał niezwykle ograniczony zasięg, skoro aż dwóch przedstawicieli z Wałcza znalazło się w krajowych władzach KZMP, w których zdecydowaną przewagę mieli reprezentanci dużych ośrodków miejskich ${ }^{69}$.

Podsumowując: PZPR w czasie przełomu zapoczątkowanego w $1980 \mathrm{r}$. nie odważyła się na dokonanie strategicznego zwrotu, do którego została zmuszona niecałą dekadę później. Górę wzięły presja zewnętrzna i dyktowana względami taktycznymi asekuracja, co pozwoliło partyjnemu aparatowi podporządkować sobie kontestatorów z prawa i lewa. Ci ostatni po zjeździe partii przekształcili się w Seminarium Marksizmu-Leninizmu. I, jak się wydaje, świadczyć to może nie tyle o zagubieniu ideowym, ile o bezsilności, gdyż z braku społecznego poparcia ci ortodoksyjni komuniści czy przeciwnicy zmian następujących w Polsce szukali platformy, która pozwoliłaby im przetrwać. Stąd doszło do fuzji partyjnej ortodoksji i nacjonalizmu, czego wyrazem była symbioza ruchu klubów „Rzeczywistości” i Zjednoczenia Patriotycznego "Grunwald"70. Jednym z jego ogniw był Klub Wiedzy Społeczno-Politycznej, który pod patronatem „Rzeczywistości” powstał w Poznaniu. Na inauguracyjnym zebraniu 6 listopada 1981 r. w Domu Technika, w którym - co znamienne - wziął udział uchodzący za jednego z liderów frakcji twardogłowych Tadeusz Grabski, redaktor pisma Brzeziński

\footnotetext{
ży", AAN, KC PZPR, sygn. XI/932, k. 315 (Informacja o aktualnej sytuacji w ruchu młodzieżowym z 19 IX 1981).

67 „Młody Komunista” 1981, nr 3 (listopad-grudzień), s. 4.

${ }^{68}$ Archiwum Państwowe w Pile, KW PZPR, sygn. 99, k. 141.

${ }^{69}$ Znaleźli się oni w czterdziestoosobowym składzie Krajowego Komitetu KZMP, w którym był jeden przedstawiciel Poznania, patrz: „Młody Komunista” 1981, nr 3 (listopad-grudzień), s. 10.

${ }^{70}$ P. Gosztald-Seń, Koncesjonowany nacjonalizm, s. 235.
} 
nie krył, że wśród priorytetów projektu jest „przeciwstawienie się kontrrewolucji, która już nawet nie próbuje markować swoich celów. Mamy konkretny program - linię marksistowsko-leninowską. Jeśli ktoś się wstydzi słowa komunista to $\mathrm{z}$ takim nam nie po drodze" 71 .

Jednak po przełomie zapoczątkowanym w sierpniu 1980 r. zdecydowana większość nie upatrywała lekarstwa na wyjście z najgłębszego kryzysu, w jakim znalazła się Polska, w powrocie do rozwiązań sięgających do komunistycznej ortodoksji. Wielkopolska nie była wyjątkiem, i tu bowiem zwolennikami „powrotu przeszłości” było bardzo niewielu. Ich personifikacją stał się Jan Majerczak, który reprezentował poglądy skrajne, wręcz sekciarskie - jak wielu członków partii, odwołujących się do dawnego wokabularza ruchu komunistycznego, gdy przeciwników chciano zdyskredytować, inicjatywę tę określano. Próba skojarzenia ideologicznej ortodoksji z elementami nacjonalistycznymi i antysemickimi oznaczała nie tylko sprzeciw wobec zmian dokonujących się w PZPR, ale była również objawem bezradności i skazywała ją rzeczywiście na niewiele znaczący polityczny margines ${ }^{72}$. To właśnie wytknął mu jeden ze starszych działaczy partyjnych Lamprycht, który zarzucił mu sekciarstwo i szkodzenie partii. A to, zdaniem zdecydowanej większości działaczy PZPR, eksperyment ów skazywało na jej margines.

I faktycznie ruch ten ani w Polsce, ani w Wielkopolsce nie odegrał większej roli. W podzielonej na frakcje PZPR to właśnie odłam zachowawczy okazał się najsłabszy. Był znacznie słabszy od swego największego wroga, a więc od grupy prących do reform i przekształcenia jej w partię typu socjaldemokratycznego. Partyjny „beton” nie stanowił również wielkiego ideowego i organizacyjnego zagrożenia dla zdobywającej zdecydowaną przewagę formacji zwolenników częściowej liberalizacji i zachowania organizacyjnej zwartości PZPR.

Tym samym podjęta również w Poznaniu próba, aby „z lewa” przeciwstawić się zmianom w partii, musiała skończyć się fiaskiem.

Zupełnie na marginesie, odmienną i wolną od nacjonalizmu oraz jeszcze silnej osadzoną w ideologicznej ortodoksji była propozycja bardzo nielicznego grona młodych komunistów skupionych w KZMP, ale również ta oferta spotkała się z całkowitą obojętnością ze strony rówieśników. W obliczu wielkiej społecznej i politycznej mobilizacji, w warunkach państwa o monopoli-

71 „Gazeta Poznańska” nr 220, 9 listopada 1981 r. Jak wspomniano wcześniej, na czele grupy inicjatywnej zmierzającej do powołania poznańskiego klubu „Rzeczywistości” stał Czubiński, który jednak wycofał się z tego przedsięwzięcia na krótko przed zebraniem założycielskim. Jako otwierającego zebranie założycielskie zastąpił go prof. Akademii Medycznej Mieczysław Wender, który wraz Majerczakiem został członkiem kilkunastoosobowej Rady Programowej Klubu, a ten za swego patrona wybrał Marcina Kasprzaka.

72 "Gazeta Krakowska” nr 219 z 9 listopada 1981 r.; „Obserwator Wielkopolski” nr 24 z 11 listopada $1981 \mathrm{r}$. 
stycznej strukturze władzy, gdy pojawił się ruch, który rzucił wyzwanie dominującej sile, doszło do naturalnej polaryzacji, gdzie zabrakło miejsca dla alternatywnych i sięgających w przeszłość propozycji, ale - co najistotniejsze - w oczach większości wizje te zostały zdyskredytowane i żadną miarą orientacje o proweniencji wywodzącej się z tych, które leżały u źródeł głębokiego kryzysu, nie mogły uzyskać większego poparcia. Te próby nie miały szans na powodzenie. Partia skazana została użycie siły, a później na dryfowanie, które po nieudanych próbach wyjścia z impasu, doprowadziło w końcu do jej klęski i utraty władzy.

Na koniec warto zadać pytanie, dlaczego w momencie najgłębszego załamania systemu, budowanego od 1944 r. i targanego co rusz kryzysami, mimo to chciano wrócić do korzeni i odwołać się do komunizmu. Skąd ta fascynacja nim? Tego rodzaju złudzeń raczej nie miała przecież większość społeczeństwa. Mirosława Marody zauważyła przed laty, że „[...] podobieństwa między postawami społecznymi z początku i końca okresu PRL kusiły, by sformułować tezę o zasadniczym odrzucaniu systemu komunistycznego przez polskie społeczeństwo. Mimo że pokusa ta jest nadal silna, nie należy jej jednak ulegać. Nie jest bowiem tak, by stosunek społeczeństwa polskiego do władzy komunistycznej, a zwłaszcza głoszonej przez nią ideologii, jak również wzory działań w obrębie systemu, pozostawały przez 45 lat niezmienne" ${ }^{73}$. O ile stosunek społeczeństwa zawrzeć można w bardzo syntetycznej formule, której użył (za Krystyną Kersten) Andrzej Friszke: „przystosowanie i opór"74, to nie odnosiła się ona do najbardziej „twardego jądra” w PZPR. Dla niego ostatnią szansą był powrót do źródeł. A źródła tkwiły bardziej w wierze niźli pragmatycznej ocenie rzeczywistości, co Marcin Kula celnie nazwał „religiopodobnym komunizmem" ${ }^{75}$.

\section{Bibliografia}

\section{Źródła archiwalne}

Archiwum Akt Nowych, KC PZPR, sygn. XI/932, XI/1303. XI/932.

Archiwum Państwowe w Pile, KW PZPR, sygn. 99.

Archiwum Państwowe w Poznaniu, Komitet Wojewódzki Polskiej Zjednoczonej Partii Robotniczej, sygn. 26, 163, 492, 493, 1232, 1673, 3579.

\section{Wspomnienia}

Brygier J. Trudne lata 1980-1984, s.6 (maszynopis nieopublikowanych wspomnień, udostępniony autorowi przez Edwarda Skrzypczaka).

73 M. Marody, Przemiany postaw ideologicznych i przystosowanie w systemie komunistycznym, [w:] Komunizm. Ideologia, system, ludzie, red. T. Szarota, Warszawa 2001, s. 128-129.

${ }^{74}$ A. Friszke, Przystosowanie i opór. Rozważania nad postawami społecznymi 1956-1970, [w:] tamże, 139 i n.

${ }^{75}$ M. Kula, Religiopodobny komunizm, Kraków 2003, s. 113 i n. 
Kolasiński M., Zapiski nie tylko autobiograficzne, cz. III, Poznań 2008, cz. IV, Poznań 2009 (maszynopis udostępniony przez autora).

Relacje

Jan Dutko

\section{Źródła drukowane}

Narady i telekonferencje kierownictwa PZPR w latach 1980-1981, red. M. Jabłonowski, W. Janowski, W. Władyka, Warszawa 2004.

„Biuletyn Komitetu Wojewódzkiego PZPR w Poznaniu” nr 2 z 12 lutego 1981 r.

„Express Poznański” nr 145 z 30 lipca 1981 r., nr 126 z 2 lipca 1981 r.

"Gazeta Krakowska" nr 219 z 9 listopada 1981 r.

„Gazeta Poznańska” nr 120 z 22 czerwca 1981 r., nr 122 z 24 czerwca 1981 r., nr 124 z 26/28 czerwca 1981 r., nr 148 z 30 lipca 1981 r., nr 150 z 3 sierpnia 1981 r., nr 204 z 16 października 1981 r., nr 220 z 9 listopada 1981 r.

"Gazeta Zachodnia" nr 83 z 29 kwietnia 1981, nr 91 z 11 maja 1981 r.

"Głos Wielkopolski" nr 220 z 9 listopada 1981 r., nr 223 z 12 listopada 1981 r.

„Lewą! Biuletyn Dyskusyjny Uniwersyteckiej Organizacji Partyjnej” 1980, nr 1 (grudzień), 1981, nr 2 (styczeń), 1981, nr 3 (luty), nr 5.

„Młody Komunista” 1981, nr 3 (listopad-grudzień).

"Obserwator Wielkopolski" nr 24 z 11 listopada 1981 r.

„Przegląd Poznański” 1988, nr 1.

„Rzeczywistość” nr 7 z 5 lipca 1981 r., nr 28 z 29 listopada 1981 r.

\section{Opracowania}

Bäcker R., Struktury poziome w Toruniu: (1980-1981), Warszawa 1990.

Bosacki Z., Jeśli dziś nie wolno, to nie wolno się bać - tekst przygotowany do druku w poznańskim „Tygodniu”, który się nie ukazał po wprowadzeniu stanu wojennego.

Choniawko A., PZPR w Wielkopolsce 1948-1984, Poznań 1987.

Cyfert Sz., Krzakiewicz K., Wspomnienie o profesorze J. Boroniu, „Organizacja i Kierowanie” 2011, nr 1(144), s. 7-9.

Czerwiński Z., Walka o komitet, „Przegląd Poznański” 1988, nr 1, s. 10.

Duraczyński E., PZPR w kryzysie - kryzys w PZPR (lato 1980-lato1981), „Dzieje Najnowsze” 1997, nr 4, s. 79.

Gosztald-Seń P., Dogmatyczna fronda w PZPR. Dziatalność Katowickiego Forum Partyjnego w roku 1981, [w:] Elity komunistyczne w Polsce. Warszawa-Lublin 2015, s. 357-389.

Gosztald-Seń P., Koncesjonowany nacjonalizm. Zjednoczenie Patriotyczne Grunwald 1980-1990, Warszawa 2012.

Jankowski W., Członkowie Polskiej Zjednoczonej Partii Robotniczej wobec wprowadzenia stanu wojennego, [w:] Kościót i społeczeństwo wobec stanu wojennego, red. W.J. Wysocki, Warszawa 2004, s. 451-453.

Junes T., Student Politics in Communist Poland: Generations of Consent and Dissent, Lanham 2015.

Kazimierski J., Katowickie Forum Partyjne, „Pamięć i Sprawiedliwość” 2013, t. 22, nr 2.

Wiktor Z., Komunistyczny ruch młodzieżowy w Polsce, [w:] Młode pokolenie Polski, red. B. Rogowska, Wrocław 2000.

Wierzbicka A., Jezzyk antytotalitarny w Polsce: o pewnych mechanizmach samoobrony jezykowej, „Teksty Drugie: teoria literatury, krytyka, interpretacja” 1990, nr 4, s. 27.

"Lewica" PZPR. Działalność Stowarzyszenia Klubów Wiedzy Społeczno-Politycznej „Rzeczywistość" w latach 1981-1983, [w:] Letnia Szkoła Historii Najnowszej, red. Ł. Kamiński i T. Kozłowski, Warszawa 2010, s. 77. 
Krzysztof Rzepa

\title{
Nostalgia i rewolucyjny zapał - na obrzeżach PZPR: Poznańskie Forum Komunistyczne i Komunistyczny Związek Młodzieży Polskiej w Wielkopolsce w 1981 r.
}

\begin{abstract}
Streszczenie
Po sierpniu 1980 r. doszło do kryzysu wewnątrz rządzącej PZPR. Wyłoniły się w niej dwa skrajne skrzydła, które obok najliczniejszego i zwycięskiego centrum, próbowały doprowadzić do głębokiej reformy partii $\mathrm{w}$ duchu socjaldemokratycznym (tzw. struktury poziome), a z drugiej strony - z nimi zdecydowanie walczące $\mathrm{w}$ imię ideologicznej ortodoksji - gremia odwołujące się do komunizmu czy wręcz stalinizmu. Te ostatnie były najmniej liczne i wpływowe, ale cieszyły się poparciem części odsuniętego od władzy aparatu PZPR. W tym nurcie istotną rolę (obok grup katowickiej i warszawskiej) odgrywało Poznańskie Forum Komunistów. Obok podobieństw miedzy nimi, jedną z cech odróżniających grupę poznańską był słabiej przez nią artykułowany ideowy dogmatyzm, co wynikało z liczniejszego w niej grona odsuniętych od władzy przez silnych w Poznaniu reformatorów młodszych działaczy partyjnych, którzy PFK potraktowali instrumentalnie jako sposób na odzyskanie wpływów.
\end{abstract}

Słowa kluczowe: Wielkopolska 1980/1981, walka o kształt i władzę w PZPR

\section{Nostalgia and revolutionary passion - on the outskirts of the Polish United Workers' Party: the Poznań Communist Forum and the Communist Association of Polish Youth in Greater Poland in 1981}

\begin{abstract}
Following the events of August 1980, the ruling Polish United Workers' Party (PUWP) was hit by a crisis. Within the party, two radical groups (the so-called "horizontal structures") emerged next to the largest and most influential "center". They tried to introduce deep social-democratic reforms in the Party. On the other hand, there were groups that heavily opposed them in the name of communist or even Stalinist doctrine. The latter groups were the smallest and least influential, but they enjoyed support of some PUWP authorities who had lost power. A significant role in this movement was played by the Poznan Communist Forum, along with groups from Katowice and Warsaw. There were some similarities among those groups, but one feature that clearly distinguished the Poznań group from the rest was a smaller emphasis on ideological dogma. This resulted from the fact this group included more younger party activists, who lost their power in Poznań to the reformers, and who treated the Forum just as a means to regain their influence.
\end{abstract}

Key words: Greater Poland 1980/1981, fight for the power and shape of the PUWP 